\title{
不同視弱視，斜視弱視，形態覚遮断弱視 の空間周波数特性
}

\author{
森 \\ 由美子・須田和代 - 調廣子 \\ 関 谷善, 文・山本節 \\ （神戸大学医学部眼科学教室） \\ Contrast Sensitivity Analysis in Amblyopia Cases \\ Yumiko Mori, Kazuyo Suda, Hiroko Shirabe \\ Yoshibumi Sekiya and Misao Yamamoto \\ Department of Ophthalmology, School of Medicine, Kobe University
}

我々は, VISTECH 社製の MCT 8000 を用いて各種弱視の視標輝度の変化におけるコントラスト感度を調べ たので報告する。不同視弱視では, 視標輝度が変化すると健眼同様コントラスト感度は低下を示したが, 斜視 弱視では低下を示さなかった。一方, 形態覚遮断弱視はかなり重篤な視機能障害を含む症例が多かったことも あり，明らかな傾向は確認できなかった。

We measured changes in contrast sensitivity functions of 20 anisometropic, 20 strabismic, and 5 deprivation amblyopic eyes in response to changes of luminance in patients aged between 5 to 12 years using the MCT 8000 under three kinds of luminances-DAY VISION ( $40 \mathrm{foot}-\mathrm{Ls}=137 \mathrm{~cd} / \mathrm{m}^{2}$ ), DAY VISION with Kodak N.D. filter 2.0 and N.D. filter $3.0\left(0.4\right.$ foot-Ls $=1.37 \mathrm{~cd} / \mathrm{m}^{2}, 0.04$ foot-Ls $=$ $0.137 \mathrm{~cd} / \mathrm{m}^{2}$ ). Contrast sensitivity values of anisometropic amblyopic eyes under DAY VISION with N.D. 2.0 and N.D. 3.0 were lower at all spatial frequencies. Those of strabismic amblyopic eyes with N.D. 2.0 and N.D. 3.0 were not lower at high spatial frequencies as compared to the result of the contrast sensitivity under DAY VISION. The contrast sensitivity of deprivation amblyopia was observed to be extremely low at all spatial frequencies. We think that the contrast sensitivity is a useful and an effective way of determining the clinical course amblyopia.

\section{I. 緒 言}

従来より, 弱視眼では低輝度下において正常 眼とは異なり視力は低下しないといわれている が $^{1)}$ ，これをコントラスト感度において検討し た報告は少ない2３）。今回我々は，視標輝度の

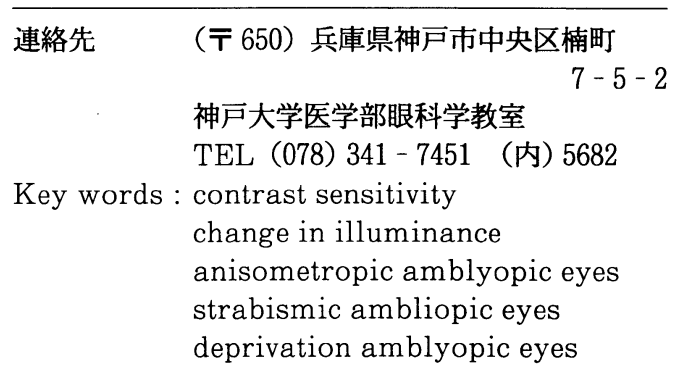

変化が弱視眼の視覚に及ぼす影響を調べるため, VISTECH 社製の MCT 8000 (図 1) を用いて, 治療中の不同視弱視, 斜視弱視, 形態覚遮断弱 視のコントラスト感度を測定し, 統計学的に検 討したので報告する。

\section{II. 対象と方法}

\section{1) 対象}

平成 6 年 1 月から平成 7 年 8 月まで当科斜視 弱視外来で治療中の不同視弱視症例 20 例, 斜 視弱視症例 20 例, 形態覚遮断弱視症例 5 例であ る。年踚は 5 歳 12 歳である。 


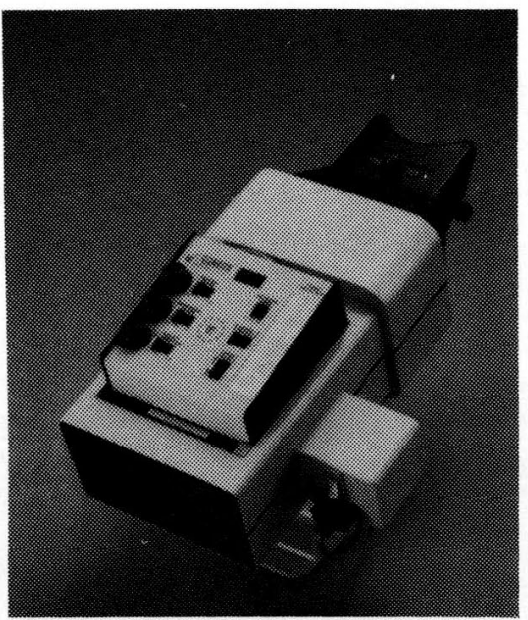

図 1 MCT 8000

\section{2) 方法}

VISTECH 社製の MCT 8000 を用いて，視標 輝度を昼間視 DAY VISION (40 footLs $=137$ $\left.\mathrm{cd} / \mathrm{m}^{2}\right)$ と, 昼間視でコダック社製 N.D フィル ター2.0，3.0を負荷した（0.4 footLs $=1.37 \mathrm{~cd}$ $/ \mathrm{m}^{2}, 0.04$ foot-Ls $=0.137 \mathrm{~cd} / \mathrm{m}^{2}$ ) (以下 N.D. 2.0, N.D.3.0 と略す) 合計 3 条件に設定し, 各 条件下で遠方視のコントラスト感度を片眼ずつ 測定した。検查時, 被検者は矯正眼鏡装用のう え view piece より筒内を咞き, 正弦格子縞の方 向を視認できうる最小コントラストの視標まで 指あるいは口頭で答えてもらう。7 個 1 組の視 標の周波数は $1.5,3 ， 6 ， 12,18$ cycles/degree の 5 種類で, 各組 1 から 7 の順でコントラスト

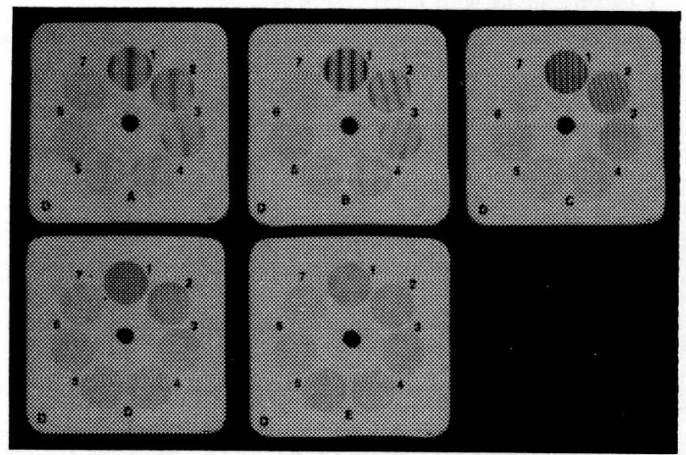

図 2 MCT 8000 の筒内視標
が低下している（図 2)。各周波数ごとで正答 できた最小コントラストをコントラスト感度と $し$, Wilcoxon paired 検定で統計学的に比較検 討をおこなった。

\section{III. 結 果}

1）不同視弱視症例のコントラスト感度は, 図 3 に示すごとく健眼，患眼ともに N.D. 2.0, N.D. 3.0 のほぼ全周波領域において有意に 低下していた。
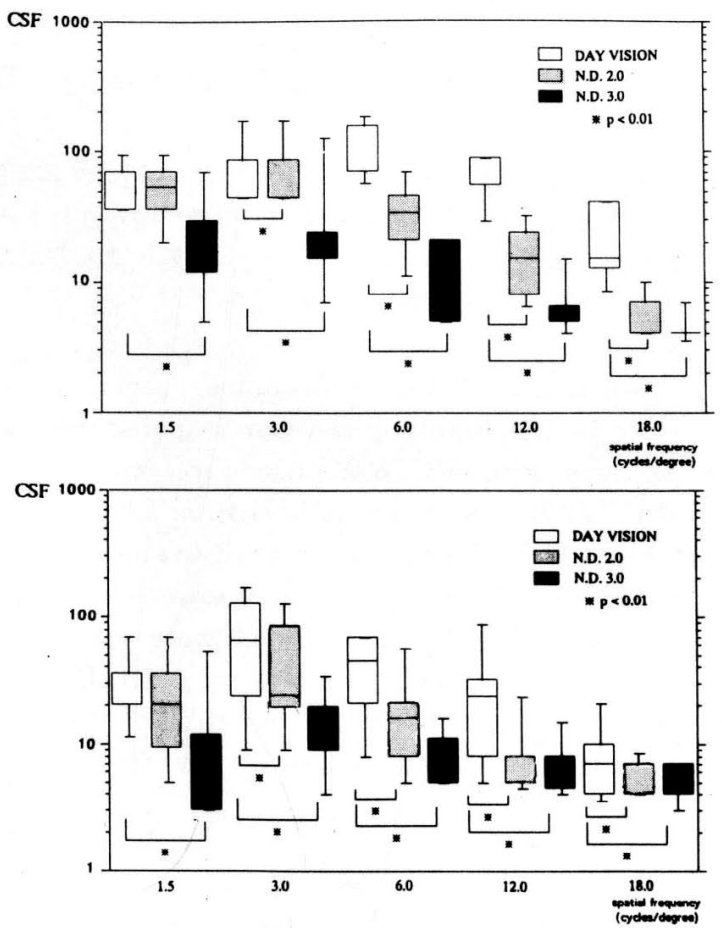

図 3 不同視弱視症例の CSF 上段 : 健眼 下段 : 患眼

2）斜視弱視のコントラスト感度は, 図 4 に示 すごとく健眼では不同視弱視と同様の傾向 であった。患眼では, DAY VISION 下での 測定結果に比べて N.D. 2.0, N.D. 3.0 とも に高周波領域においてコントラスト感度は, 健眼で示されたような有意な低下は示さな かった。

3）形態覚遮断弱視については表 1 に示すごと 


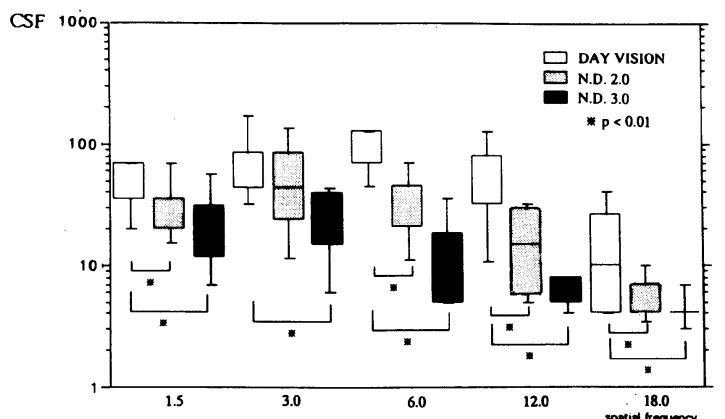

CSF

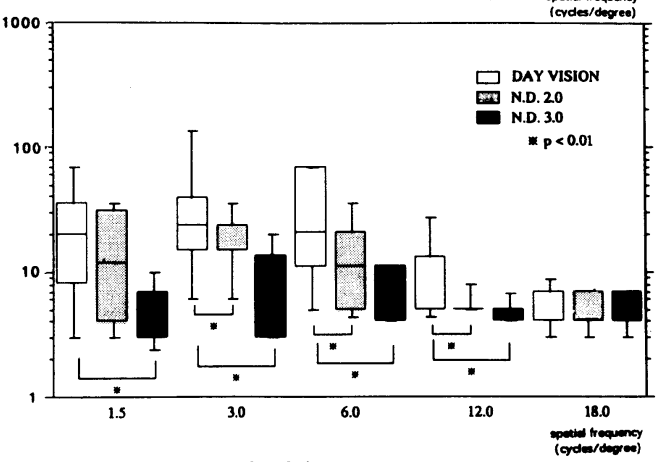

図 4 斜視弱視症例の CSF 上段 : 健眼 下段 : 患眼

く弱視眼のコントラスト感度は, 全周波領 域においてどの視標も全く視認できず測定 はできなかった。

\section{IV. 考 按}

Ammann (1921) は, 弱視眼では, 正常眼と 異なり低照度下において視力低下は起こらない ことを報告し ${ }^{1)}$ 現在む支持されている。また，
Hess らは低輝度下の弱視眼のコントラスト感 度に関する研究を行い, 不同視弱視症例ではコ ントラスト感度は低下し, 斜視弱視症例ではコ ントラスト感度の低下は示さなかったと報告し た2) 3)。

今回我々は, MCT 8000 を用いて視標輝度の 変化におけるコントラスト感度を測定した結果, 不同視弱視眼では健眼同様ほぼ全周波領域で有 意にコントラスト感度が低下していた。

すなわち不同視弱視症例では視標輝度の変化 がコントラスト感度に強く影響する健眼と同じ パターンを示しており，不同視弱視による機能 低下はコントラスト感度の変化には関与してい なかった。一方, 斜視弱視症例の弱視眼では, 高周波領域の有意な低下は示さず，健眼及び不 同視弱視に比べ視標輝度の変化による影響は極 めて少なく，斜視弱視による機能低下がコント ラスト感度の変化に関与していることが判明し た。これらは，むしろ Hess ら ${ }^{2)}$ 3) の報告と一 致するもので, 前述の $\mathrm{Ammann}^{1}{ }^{1)}$ の報告にあ る弱視とはむしろ斜視弱視ではないかと示唆さ れる。今回, 弱視の中で最も予後が不良とされ る形態覚遮断弱視を調べたが, 全周波領域にお いてほとんどコントラスト感度は観察できなかっ た。これは， 5 症例とも他の弱視に比べかなり 低視力であったため各視標の正弦格子縞が認識 できなかったと考えられる。

弱視は, 種々の型に分類され，それぞれによ り病態, 予後が異なる。健眼同様, コントラス

表 1 形態覚遮断弱視症例

\begin{tabular}{|c|c|c|c|c|c|}
\hline 症例 & 疾患名 & 年砽 & 屈折值 & $\begin{array}{l}\text { 違見眼位 } \\
\text { 近見眼位 }\end{array}$ & コントラスト感度 \\
\hline 1 & 水晶体亚脱臼 & 6 歳 & $\begin{array}{l}\mathrm{RV}=(0.2 \times-11.0) \\
\mathrm{LV}=(0.2 \times-11.0)\end{array}$ & $\begin{array}{l}25 \triangle X T \sim P \\
20 \triangle X T \sim P\end{array}$ & CSF測定不能 \\
\hline 2 & $\begin{array}{l}\text { 先天性 } \\
\text { 白内障術後 }\end{array}$ & 7 墄 & $\begin{array}{l}\mathrm{RV}=1.2(\mathrm{n} . \mathrm{c}) \\
\mathrm{LV}=(0.03 \times \\
+18.0)\end{array}$ & $\begin{array}{l}10 \triangle E P \sim T \\
10 \triangle E P \sim T\end{array}$ & CSF測定不能 \\
\hline 3 & $\begin{array}{l}\text { 先天性 } \\
\text { 白内障術後 }\end{array}$ & 8 歳 & $\begin{array}{l}\mathrm{RV}=(1.5 \times+2.0) \\
\mathrm{LV}=(0.2 \times+21.0)\end{array}$ & $\begin{array}{l}12 \triangle \mathrm{ET} \\
12 \triangle \mathrm{ET}\end{array}$ & CSF測定不能 \\
\hline 4 & $\begin{array}{c}\text { 先天性 } \\
\text { 白内障術後 }\end{array}$ & 9 歳 & $\begin{array}{l}\mathrm{RV}=1.0(\text { n.c) } \\
\mathrm{LV}=(0.1 \times+21.0)\end{array}$ & orthophoria & CSF測定不能 \\
\hline 5 & $\begin{array}{l}\text { 先天性 } \\
\text { 白内障術後 }\end{array}$ & 12 歳 & $\begin{array}{l}\mathrm{RV}=(0.2 \times \\
+15.5) \\
\mathrm{LV}=1.2 \text { (n.c) }\end{array}$ & orthophoria & CSF測定不能 \\
\hline
\end{tabular}


ト感度が低下した不同視弱視は，機能障害の軽 いタイプの弱視と考えられ，一方健眼と異なり コントラスト感度が低下しなかった斜視弱視は 機能障害の強い治療に反応しにくいタイプであ ると考えられる。形態覚遮断弱視については， 視標輝度変化におけるコントラスト感度は観察 できなかったが，他の弱視に比べ極めて機能的 障害が強いことが示唆された。今後は, 症例数 を増やし, 治療前後のコントラスト感度の経時 的な検討むしていきたい。

\section{V. 要約}

不同視弱視, 斜視弱視, 形態覚遮断弱視症例 のコントラスト感度を測定した。低輝度下にお いて不同視弱視症例では, 健眼同様ほぼ全周波 領域においてコントラスト感度が低下しており， 斜視弱視症例では, 高周波領域においてコント ラスト感度の低下は見られなかった。形態覚遮
断弱視症例では, 全周波領域においてコントラ スト感度は観察できなかった。種々の視標輝度 におけるコントラスト感度の変化のパターンが 弱視の機能障害と関係していることが示唆され た。

\section{文 献}

1) Ammann $E$ : Einige Beobachtungen bei den Funktionsprünfungen in der Sprechstunde : Zentrals Schen der Glaukomatösen.

Schen der Amblyopen, Klin Augenheik., $67: 564-570,1921$.

2) Hess RF, Campbell FW, et al : Differences in the neural basis of human amblyopias : The effect of mean luminance. Vision Res., $20: 295-305,1980$.

3) Hess RF, Howell ER : The luminance-dependent nature of the visual abnormalities in strabismic amblyopia. Vision Res., 18 : 931-936, 1978. 